\title{
Organizational conflict management techniques and their relationship to administrative creativity employed in sports clubs
}

\section{Dr. Amin Mahmoud Gaafar}

Assistant Professor, Department of Sports Management and Recreation Faculty of Physical Education for Men ,Alexandria University

\section{Introduction}

Organizations in order to achieve its objectives seek to make the most of the human and material resources, the basic foundation upon which organizations in achieving the goals they are working in, where they interact with each other continuously in order to achieve the organization's goals, and leads this interaction agreement on some things and disagreement about some And often leads to disagreements and conflict among workers .

This interaction can lead to the proficiency of employees to perform their duties in some situations or oppose them and their differences in other positions in the work environment, This conflict or difference often leads to conflict .

Ahmed Mustafa (2000) explains that organizational conflict within organizations is one of the fundamental aspects as long as it deals with human beings. It is obvious that the conflict is formed, since it is the custom of people to agree in some aspects and differences in other aspects. The conflict is a new old feature. Since the first conflict between Cain and Abel, to this day, the causes of conflict are one and the same is the difference in attitudes and thinking. (3: 425)

Refers wasal muwmin (2011) points out, the emergence of a form of conflict within organizations is one of the forces of change. Therefore, what distinguishes the effective leader from others is in how he manages the conflict. The successful leader realistically identifies conflicts within 
organizations and tries to identify the main reasons. Faces the crisis situation and does not evade it, in order to solve the problem and use conflict as a force for change . (18: 15)

Khair Hamoud (2002) explains that conflict is a natural phenomenon in the lives of individuals, groups, organizations and societies alike. Conflict is one of the usual secretions of the social interaction between individuals such as cooperation, competition, appeasement, imitation and simulation of natural phenomena in social relations and interactions. Because stability and stability is an abnormal situation, so conflicts often accompany changes in the overall relationships. Therefore, the conflict has received widespread attention from various thinkers and scholars to the organizational conflict . (9:124)

Amer al-Kubaisi (1998) asserts that conflict is one of the organizational challenges facing organizations and organizational challenges that may be in the form of internal conflicts or conflicts or between the organization and other organizations that deal with them. ( $4: 27)$

The boards of clubs should not stand idly by in the face of existing conflicts, but should intervene, because if the conflict is neglected within the sports bodies or they fail to confront them or deal with them, they will expand and become a factor of demolition and hindrance that prevents them from achieving their goals and low efficiency .

Concur Salem Al-Qahtani (2002) and Hussein Aref (2001) agree that there are a number of factors that cause a conflict between workers, namely, "organizational coordination, rushing to possess power and influence, differences in scientific and practical capabilities, differences in values and norms, , and the organization is accustomed to foreign expertise, employee relations at work, poor participation in work, difficulty in obtaining information, and imbalance of human resources. (17:153) (6:68)

The researcher contends that the organizational conflict within the sports institutions is as follows:

- Conflict within the individual itself occurs as a result of the contradiction of the individual with his goals and also with the roles performed within the sports clubs.

- Conflict between individuals occurs when the views vary between two people and occurs between the manager and his subordinates and between the coach and the coach, and between the coach and the manager. 
- Conflict between groups occurs between two groups or two departments within the club .

And the emergence of many of the many changes and challenges facing the sports institutions, which need a creative leader needs a creative leader can meet the challenges, and find solutions and innovative proposals that contribute to the achievement of its objectives and also to achieve competitive advantage .

the view of Salem Al-Qahtani (2002), the use of creative interpersonal skills by the staff to devise new management methods or to provide innovative solutions to an administrative problem facing the interest of the organization or new perceptions to address this problem based on the purposeful analysis and organized creative effort related to the perception based on analysis, selection, experimentation and evaluation . (17:327)

Hussein Arif (2001) explains that administrative innovation is a process that produces new work that the group accepts and accepts as useful. Creativity is something new and unusual, acceptable to the group as important and useful. (6:23)

The researcher believes that administrative innovation is an integrated system in which the organization and members of the organization participate from a director, a board of directors and employees, as well as the organization's environment. Management is the active factor in the organization's performance and therefore it has to move towards development to achieve its objectives. It is practiced by employees in the performance of their work, and therefore is not expected to show them creativity and excellence that contributes to the advancement of development for the better, and in view of the elements of the creative process, the cornerstone in which is the employee from which the organization starts towards administrative innovation, A subject to stand on the work environment and their dimensions and their relationship in the administrative creativity .

\section{research goals :-}

The aim of the research is to identify the methods of managing the organizational conflict and its relation to the administrative creativity of the employees of sports clubs in the Kingdom of Bahrain 


\section{Search questions: -}

- What are the methods of managing organizational conflict in sports clubs in the Kingdom of Bahrain?

- What are the areas of administrative innovation in sports clubs in the Kingdom of Bahrain?

- Is there a relationship between the methods of organizational conflict management and administrative creativity in sports clubs in the Kingdom of Bahrain?

\section{Search procedures : -}

- Research Methodology: The researcher used the descriptive approach to the nature of the research.

- Research community: includes members of the boards of directors of sports clubs and managers of clubs and employees of sports clubs "Al Ahli Muharraq - Riffa - Hadad - Bahrain - al shabab - Al Malkiya - Manama" Research sample: Board members and directors of clubs "Ahli - Muharraq Riffa - Bahrain - Malikya - Manama" and the number of (44) . member, and some employees of these clubs and the number of (72) workers at the club.

Table (1) Characterization and distribution of the sample groups on the exploratory study and the basic study

\begin{tabular}{|l|l|c|c|c|c|c|}
\hline $\begin{array}{l}\text { Sports } \\
\text { activities and } \\
\text { clubs }\end{array}$ & \multicolumn{1}{|c|}{ Club } & $\begin{array}{c}\text { Board of } \\
\text { Directors }\end{array}$ & $\%$ & Members & $\%$ & Total \\
\hline \multirow{2}{*}{$\begin{array}{l}\text { Survey } \\
\text { Study }\end{array}$} & Alshabab & 6 & 54.55 & 5 & 55.56 & 11 \\
\cline { 2 - 7 } & Alhad & 5 & 45.45 & 4 & 44.44 & 9 \\
\hline \multicolumn{1}{|l|}{ Basic Study } & Total & 11 & & 9 & & 20 \\
\cline { 2 - 7 } & Al ahly & 8 & 18.18 & 13 & 18.05 & 21 \\
\cline { 2 - 7 } & Almuharaq & 6 & 13.64 & 12 & 16.67 & 18 \\
\cline { 2 - 7 } & Alrifae & 7 & 15.91 & 13 & 18.05 & 20 \\
\cline { 2 - 7 } & Bahrain & 8 & 18.18 & 11 & 15.28 & 19 \\
\cline { 2 - 7 } & Almalikia & 8 & 18.18 & 12 & 16.67 & 20 \\
\cline { 2 - 7 } & almanama & 7 & 15.91 & 11 & 15.28 & 18 \\
\hline \multicolumn{2}{|l}{ Total } & 44 & 37.93 & 72 & 62.07 & 116 \\
\hline
\end{tabular}




\section{Data collection tools:}

- A questionnaire form was used by the researcher and followed the following steps to design it:

- To conduct a survey of the theoretical studies, scientific research and related references, to determine the axes of the questionnaire according to the objectives set, to identify the words of the words that express the axes of the questionnaire, to present the questionnaire in its initial form to a group of experts in the field of sports management (8)

- The relevance of the topics to the subject of the research, the correlation of the expressions of each axis, the adequacy, comprehensiveness and relevance of the phrases.

- The percentage of agreement of experts on the questionnaire in the final form between $90 \%$ to $100 \%$ after the deletion and modification of the statements from each axis according to the views of experts to identify:

\section{The theme of the research topic.}

Link phrases for each axis.

Adequacy, comprehensiveness and relevance of the terms. .

\section{Scientific transactions of the questionnaire form}

First: Form Validation: The validity of the form was calculated in two ways

Content Validation: The researcher relied on the sincerity of the arbitrators in order to identify the appropriate period of axes and phrases and their clarity. Some statements were deleted and others were modified according to the opinions of the experts

Internal consistency: The validity of the internal measurement of the questionnaire was verified by calculating the correlation coefficient of the paragraph with the total score of the dimension to which it belongs, and between the degree of the axis and the total score of the questionnaire. The results are shown in Table (2) below. All dimensions have a high degree of honesty with the total score of the dimension to which they belong, and all values of correlation coefficients are statistically significant at the mean level $(0.01)$ 
Table (2) Correlation coefficients between the degrees of the dimensions of the scale expressions and between each dimension and the total score

$\mathbf{n}=\mathbf{2 0}$

\begin{tabular}{|l|c|c|c|c|c|}
\hline & \multirow{2}{*}{$\begin{array}{l}\text { Serial } \\
\text { number }\end{array}$} & & & \multicolumn{2}{|c|}{ Correlation coefficients between } \\
\cline { 4 - 6 } & & $\begin{array}{l}\text { Number } \\
\text { of Phrases }\end{array}$ & $\begin{array}{l}\text { Single and } \\
\text { dimension }\end{array}$ & $\begin{array}{l}\text { Dimension } \\
\text { and axis }\end{array}$ & $\begin{array}{l}\text { Axis and } \\
\text { total score }\end{array}$ \\
\hline $\begin{array}{l}\text { The first axis: management of } \\
\text { organizational conflict }\end{array}$ & & & & & 0.856 \\
\hline Competitive style & $1: 6$ & 6 & $0.759: 0.801$ & 0,742 & \\
\hline Leveling style & $7: 12$ & 6 & $0.761: 0.798$ & 0.823 & \\
\hline Avoidance style & $13: 19$ & 7 & $0.828: 0.837$ & 0.791 & \\
\hline The courtesy style & $20: 24$ & 5 & $0.852: 0.891$ & 0.705 & \\
\hline Cooperation style & $25: 30$ & 6 & $0.798: 0.812$ & 0.896 & \\
\hline $\begin{array}{l}\text { The second axis: areas of } \\
\text { administrative innovation }\end{array}$ & & & & & 0.798 \\
\hline Problem Solving & $1: 7$ & 7 & $0.872: 0.882$ & 0.810 & \\
\hline Changeability & $8: 12$ & 5 & $0.710: 0.723$ & 0.768 & \\
\hline Risk-taking & $13: 18$ & 6 & $0.786: 0.801$ & 0.881 & \\
\hline
\end{tabular}

The value of the correlation coefficient at the mean level $(0.01)=0.561$

It is clear from Table (2) above that the correlation coefficients between the dimensions of the study and the total degree of the instrument have a high degree of truth with the total degree of the instrument. Therefore, we conclude that these dimensions and their contents achieve the desired measurement objectives in the questionnaire. Correlation coefficients are statistically significant $(0.01)$

\section{Second: Stability:}

The stability of the current study instrument was calculated in the Cronbach`s Alpha method and is shown in table (3) 
Table (3) Stability coefficients of the dimensions of the axes of the questionnaire and the stability of the dimensions and axes in the Alpha Karonbach method $n=20$

\begin{tabular}{|c|c|c|c|c|c|}
\hline \multirow[b]{2}{*}{ Axles } & \multirow{2}{*}{$\begin{array}{l}\text { Serial } \\
\text { number }\end{array}$} & \multirow[b]{2}{*}{$\begin{array}{l}\text { Number } \\
\text { of Phrases }\end{array}$} & \multicolumn{3}{|c|}{ Stability coefficients } \\
\hline & & & $\begin{array}{l}\text { Single and } \\
\text { dimension }\end{array}$ & $\begin{array}{l}\text { The } \\
\text { dimension }\end{array}$ & Axis \\
\hline $\begin{array}{l}\text { The first axis: management } \\
\text { of organizational conflict }\end{array}$ & & & & & 0.812 \\
\hline Competitive style & $1: 6$ & 6 & $0.802: 0.815$ & 0,742 & \\
\hline Leveling style & $7: 12$ & 6 & $0.720: 0.733$ & 0.823 & \\
\hline Avoidance style & $13: 19$ & 7 & $0.816: 0.845$ & 0.791 & \\
\hline The courtesy style & $20: 24$ & 5 & $0.875: 0.880$ & 0.705 & \\
\hline Cooperation style & $25: 30$ & 6 & $0.711: 0.729$ & 0.896 & \\
\hline $\begin{array}{l}\text { The second axis: areas of } \\
\text { administrative innovation }\end{array}$ & & & & & 0.723 \\
\hline Problem Solving & $1: 7$ & 7 & $0.789: 0.845$ & 0.810 & \\
\hline Changeability & $8: 12$ & 5 & $0.801: 0.861$ & 0.768 & \\
\hline Risk-taking & $13: 18$ & 6 & $0.781: 0.788$ & 0.881 & \\
\hline
\end{tabular}

it is clear from Table (3) that the values of word stability coefficients are less than the constant coefficient of the dimension to which the item belongs, meaning that all the words are fixed. The intervention of the item does not reduce the total stability coefficient of the axis to which the item belongs. Stability of the questionnaire and its validity to measure

\section{Search application: -}

The researcher conducted an exploratory study on 15/3/2018 for a sample of (20) randomly selected individuals from the original community and outside the study sample. The basic study was applied on a sample of (116) person during the period from $20 / 4 / 2018$ to $20 / 5$ / 2018 . 


\section{View and discuss the results}

Table (4) Arithmetic mean, standard deviation and "T" values for the sample responses of the study on the first axis "Organizational conflict management methods in sports clubs

\begin{tabular}{|c|c|c|c|c|c|}
\hline \multirow{3}{*}{ M } & \multirow{3}{*}{ sentence } & \multirow[b]{2}{*}{$\begin{array}{c}\text { Chi } \\
\text { square }\end{array}$} & \multicolumn{3}{|c|}{$\mathrm{N}=116$} \\
\hline & & & $\begin{array}{l}\text { Arithmetic } \\
\text { average }\end{array}$ & $\%$ & Ranking \\
\hline & & & & & \\
\hline 1 & $\begin{array}{l}\text { I use my scientific and practical experience to make my colleagues } \\
\text { accept my ideas and make my opinion acceptable }\end{array}$ & 90.12 & 1.30 & 15.09 & 2 \\
\hline 2 & Always insist on a regular follow-up on the issue at stake & 90.95 & 1.40 & 19.83 & 1 \\
\hline 3 & $\begin{array}{l}\text { My ability to deal with information has given me the opportunity to } \\
\text { convince others of my solutions to solve problems }\end{array}$ & 48.48 & 1.53 & 26.72 & 6 \\
\hline 4 & $\begin{array}{l}\text { I have the power and influence that qualifies me to promote the } \\
\text { ideas and decisions I seek }\end{array}$ & 81.59 & 1.36 & 18.10 & 3 \\
\hline 5 & $\begin{array}{l}\text { I work hard to develop the issue that concerns me and protect my } \\
\text { rights as a member of the team }\end{array}$ & 69.95 & 1.58 & 28.88 & 5 \\
\hline 6 & $\begin{array}{l}\text { I discuss his case with my colleagues at work to demonstrate the } \\
\text { advantages of your career }\end{array}$ & 79.98 & 1.50 & 25.00 & 4 \\
\hline & Leveling style & & & & \\
\hline 7 & $\begin{array}{l}\text { I seek to negotiate when there is a conflict between my colleagues } \\
\text { and my colleagues in order to reach a mutually satisfactory } \\
\text { solution. }\end{array}$ & 33.17 & 1.72 & 36.21 & 4 \\
\hline 8 & $\begin{array}{l}\text { I propose a compromise to overcome the outstanding problems } \\
\text { between me and my colleagues at work }\end{array}$ & 21.59 & 1.67 & 33.62 & 6 \\
\hline 9 & $\begin{array}{l}\text { I sometimes waive some points of the case if the other party } \\
\text { waives. }\end{array}$ & 34.36 & 1.84 & 41.81 & 1 \\
\hline 10 & I sometimes waive some points of the case if the other party waives & 33.64 & 1.78 & 39.22 & 3 \\
\hline 11 & $\begin{array}{l}\text { I try to propose solutions that satisfy as much as possible all the } \\
\text { conflicting parties. }\end{array}$ & 31.52 & 1.71 & 35.34 & 5 \\
\hline 12 & $\begin{array}{l}\text { I sometimes suggest a compromise to overcome blocked roads and } \\
\text { resolve existing differences. }\end{array}$ & 34.36 & 1.84 & 41.81 & 1 \\
\hline & Avoidance style & & & & \\
\hline 13 & $\begin{array}{l}\text { I avoid conflicts in the hope that the situation will automatically } \\
\text { improve }\end{array}$ & 50.14 & 1.78 & 38.79 & 1 \\
\hline 14 & $\begin{array}{l}\text { I try hard to avoid any disagreements with my colleagues at work } \\
\text { no matter what the reasons }\end{array}$ & 60.02 & 1.49 & 24.57 & 7 \\
\hline 15 & Better avoid tension and stand up with my colleagues & 37.57 & 1.70 & 34.91 & 3 \\
\hline 16 & $\begin{array}{l}\text { I avoid opening the discussion and dialogue about any conflict } \\
\text { between me and my colleagues at work for fear of stalling things } \\
\text { and reaching a dead end }\end{array}$ & 50.29 & 1.59 & 29.74 & 5 \\
\hline 17 & $\begin{array}{l}\text { Delay in conflicts until there is enough time to scrutinize them and } \\
\text { to be able to confront them. Working out of fear of a stalemate and } \\
\text { a dead end. }\end{array}$ & 40.88 & 1.56 & 28.02 & 6 \\
\hline 18 & I try to avoid taking certain positions that can be controversial & 32.19 & 1.67 & 33.62 & 4 \\
\hline
\end{tabular}




\begin{tabular}{|c|c|c|c|c|c|}
\hline 19 & $\begin{array}{l}\text { I use various procedures and behavioral methods to avoid conflicts } \\
\text { and engage in their management }\end{array}$ & 34.88 & 1.71 & 35.34 & 2 \\
\hline & The courtesy style & & & & \\
\hline 20 & $\begin{array}{l}\text { I was often subject to the wishes of my colleagues at the time of any } \\
\text { conflicts between me and them }\end{array}$ & 60.07 & 1.67 & 33.62 & 2 \\
\hline 21 & $\begin{array}{l}\text { The most prominent points of circumvention rather than the } \\
\text { difference between the conflicting parties }\end{array}$ & 43.31 & 1.55 & 27.59 & 5 \\
\hline 22 & $\begin{array}{l}\text { I take into account the feelings of my colleagues at work, even if } \\
\text { they are different from my feelings in order to maintain good } \\
\text { working relations with them }\end{array}$ & 33.17 & 1.72 & 36.21 & 1 \\
\hline 23 & $\begin{array}{l}\text { I make sure to provide opinions and suggestions that do not hurt my } \\
\text { colleagues' feelings at work }\end{array}$ & 44.97 & 1.62 & 31.03 & 3 \\
\hline 24 & $\begin{array}{l}\text { Has become my personal goals in order to achieve other goals of the } \\
\text { sports institution }\end{array}$ & 53.40 & 1.59 & 29.31 & 4 \\
\hline & Cooperation style & & & & \\
\hline 25 & $\begin{array}{l}\text { I cooperate when any conflict arises between me and my } \\
\text { colleagues at work to understand the reality of the problem and } \\
\text { work to solve it }\end{array}$ & 107.81 & 2.63 & 81.47 & 5 \\
\hline 26 & $\begin{array}{l}\text { The best teamwork is to get solutions compared to what anyone } \\
\text { can do independently }\end{array}$ & 90.64 & 2.63 & 81.47 & 5 \\
\hline 27 & $\begin{array}{l}\text { I believe that mutual understanding and the exchange of correct } \\
\text { information among the conflicting parties may lead to satisfactory } \\
\text { solutions for all }\end{array}$ & 110.40 & 2.68 & 84.05 & 4 \\
\hline 28 & $\begin{array}{l}\text { I try to provide maximum help if asked to find the best solutions to } \\
\text { existing problems. }\end{array}$ & 118.83 & 2.72 & 86.21 & 3 \\
\hline 29 & $\begin{array}{l}\text { I would like to hear everyone's opinion on the issue and contribute } \\
\text { to forming a collective opinion to solve the problem }\end{array}$ & 119.24 & 2.74 & 87.07 & 1 \\
\hline 30 & I set common goals that require the cooperation of all & 123.22 & 2.74 & 87.07 & 1 \\
\hline
\end{tabular}

* Kay square is significant at the level of $0.05=5.99$

It is clear from Table (4) that the values of "T" calculated for the terms of the first axis are greater than the tabular value at the level of significance $(0.05)$, indicating that there are statistically significant differences between the mean and the legal average. (58.6\%), indicating that the characteristic ability of the sample of the study sample obtained a medium or near the low level. This was represented by the response to the phrase (3) "is tired of repeating the procedures followed in completing the work" And so on 


\section{The second axis: areas of administrative creativity in sports clubs}

Table (5) arithmetic mean, standard deviation and values of " $\mathrm{T}$ " for the sample responses

of the study on the second axis: areas of managerial creativity in sports clubs $n=116$

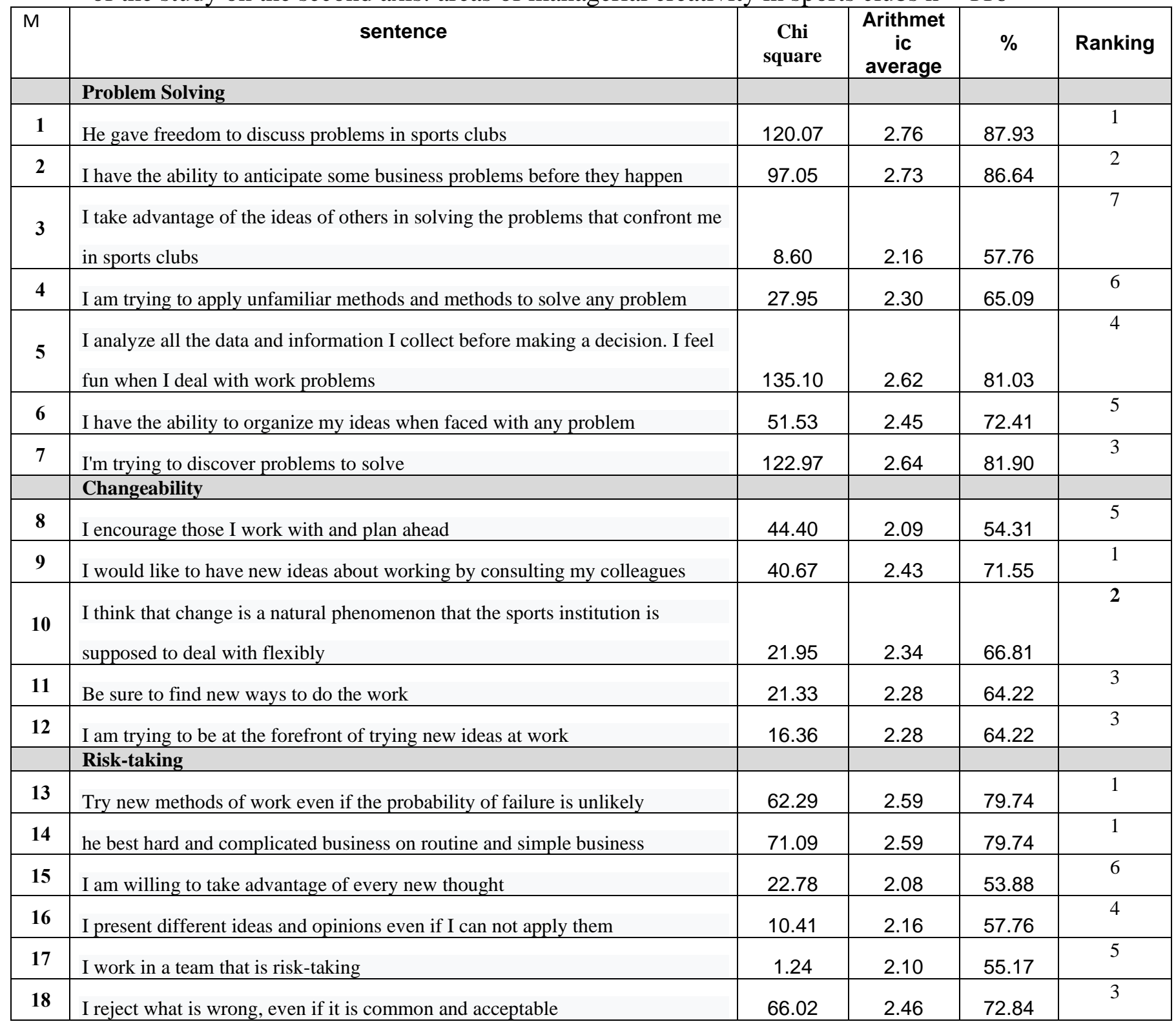

It is clear from Table (5) that the values of "T" calculated for the terms of the first axis are greater than the tabular value at the level of significance (0.05), indicating the existence of statistically significant differences between the calculated mean and the legal average. (59.87\%). This indicates that the performance of the sample of the study sample was of a medium grade. This was represented by the response to the phrase (39) "The staff shall make the necessary effort to complete the tasks required of them to the required extent and on time, The total arithmetic mean of the axis was beyond the parameters and parameters 
Performance (1.43) of the total score and percentage (47.73\%)Indicating that the criteria and performance criteria for the sample of the study sample obtained a low score. This was represented by the response to the phrase (49). The performance calendar reveals the training needs and thus identifies the necessary development and development programs

Table ( 6 ) (average) approval rate for organizational conflict management methods and management innovation

\begin{tabular}{|l|c|l|c|}
\hline Conflict Management & $\%$ & Administration & \% \\
Techniques & & creativity & \\
\hline Competitive style & 47.20 & Problem Solving & 76.11 \\
\hline Leveling style & 72.49 & Changeability & 64.22 \\
\hline Avoidance style & 57.20 & Risk-taking & 66.52 \\
\hline The courtesy style & 59.48 & & \\
\hline Cooperation style & 89.01 & & \\
\hline
\end{tabular}

Table (6) shows the average rate of approval of organizational conflict management methods and administrative innovation. The highest percentage of the methods of conflict management came in the method of cooperation with $89.01 \%$ and the rest of the methods followed. Finally, the method of competition reached $47.20 \%$ The highest rate of approval for the methods of managerial innovation was the problem solving method $(76.11 \%)$, followed by the changeability method $(66.52 \%)$, followed by the risk-taking $(64.22 \%)$.

Table (7) The correlation coefficients between organizational conflict management and management creativity in sports clubs in the Kingdom of Bahrain

\begin{tabular}{|l|c|l|l|c|l|l|}
\hline Variables & $\begin{array}{l}\text { Competiti } \\
\text { ve style }\end{array}$ & $\begin{array}{l}\text { Leveling } \\
\text { style }\end{array}$ & $\begin{array}{l}\text { Avoidanc } \\
\text { e style }\end{array}$ & $\begin{array}{l}\text { The courtesy } \\
\text { style }\end{array}$ & $\begin{array}{l}\text { Cooperation } \\
\text { style }\end{array}$ & $\begin{array}{l}\text { Conflict } \\
\text { Management } \\
\text { Techniques }\end{array}$ \\
\hline Problem Solving & 0.528 & 0.679 & 0.643 & 0.612 & 0.812 & 0.680 \\
\hline Changeability & 0.467 & 0.548 & 0.630 & 0.632 & 0.721 & 0.532 \\
\hline Risk-taking & 0.378 & 0.497 & 0.534 & 0.615 & 0.724 & 0.780 \\
\hline
\end{tabular}




\begin{tabular}{|l|l|l|l|l|l|l|}
\hline $\begin{array}{l}\text { administration } \\
\text { creativity }\end{array}$ & 0.421 & 0.532 & 0.611 & 0.618 & 0.789 & 0.882 \\
\hline
\end{tabular}

Table ( 7 ) shows that there is a significant positive correlation relationship at the level of significance (0.05) between the methods of organizational conflict management and managerial creativity among the employees of the sports clubs in the Kingdom of Bahrain where the correlation coefficient $\mathrm{R}$ between methods of organizational conflict management and administrative innovation, The correlation between the probability of change and the method of cooperation by 0.721 , and the relationship between the spirit of risk and the method of cooperation by 0.724 where the values in Table (6) are greater than the value of $r$ table at the level of significance (0.05 to 0.01) Statistical indication between This is due to the fact that if scientific methods are dealt with with the methods of managing organizational conflict, it leads to administrative innovation

The researcher believes that the use of these methods helps sports clubs to avoid problems and therefore development and survival, and here it is necessary for the management and the manager to identify the vision of the employees and clarify the objectives in addition to the development of channels of communication and administrative approach and leadership style must be exercised in a manner that entails the impact of the manager positive on the workers.

In this regard, Mahmoud Al-Omayan (2002) argues that the conflict focuses on the existence of competition and differences in attitudes, opinions and interests among workers. This is normal among human beings, but the conflict may be positive and distinctive for the benefit of the institution or is harmful and leads to functional imbalance. $(10: 42)$

Ahmed Maher (2002) and Salah Abdul Baqi (2004) agree that the correct management of organizational conflict transforms the energy generated by conflict from energy and individuals into positive benefits and outcomes for the organization. All this is done through a conflict of positive debate and intellectual storming. (2: 77) (16:25)

Rahim A (2001), Marion Beatriz (2004) agrees that the points of agreement must be sought and the points of disagreement in the institutions are avoided. This approach is characterized by its firmness, cooperation, 
recourse to power and human relations. With all parties involved and offer alternatives to the solution and discuss with the parties. (13:57) (11:79)

In this regard, Falah Hassan (2000) sees performance as a reflection of how the institution uses the material and human resources and exploits them in a way that makes them able to achieve their goals. $(5: 231)$

Randa al-Zahri (2002) states that creativity can only be achieved through an environment conducive to self-expression. It is important to encourage individuals to present new ideas, to establish guarantees for change without causing harm, and to inspire confidence in constructive criticism and encouragement, And assessing the truth under flexible systems and procedures. $(14: 258)$

The results of the present study are consistent with the results of Abdulla Al-Saleem's study (2002) ( 1 ) which found that most elements of administrative creativity are available to the original employees, fluency, risk acceptance, sensitivity to problems and the work environment. , Encouraged new ideas and provided the necessary support

A study by McClean McClean explained. E.M (2004) (12), Ray. D.K (2007) (15), the study of Isaksen. S.G. \& Geuens. D. (2007) ( 7 ) that the creativity of the individual depends on the individual's understanding of the method of knowledge and limits of productivity and help him to choose a way to solve the problem and increases the ability to choose the best solution and the appropriate strategy to reach the solution.

Isaksen \& Treffinger (2005) (8) explained that the creative solution to problems in institutions achieves the interaction between the elements of creativity, which is done with the characteristics of the creative individual

The researcher considers the importance of administrative creativity and the need for it. It is obligatory for clubs to adopt ideas for change, development and problem solving. All this is focused on improving the performance of the clubs and their effectiveness and achieving their goals. Hence, creativity can be seen as the process of adopting creative ideas and their sources. A significant shift at the level of sports clubs and their implementation by individuals, groups or clubs as a unit.

\section{Conclusions}

1- The staff of the sports clubs have the highest managerial creativity, such as solving the problems by $76.11 \%$, the changeability ratio by $66.52 \%$, the risk of $64.22 \%$. 
2. Sports clubs have organizational conflict management methods, such as $89.01 \%, 72.49 \%, 59.48 \%, 59.20 \%, 47.20 \%$ ).

3 - the existence of a relationship between the methods of organizational conflict management and administrative creativity of employees in sports clubs.

4. The staff of the sports clubs have good performance: adequate effort, dedication and seriousness, professional skill and technical knowledge, specific policies and procedures.

5. Using conflict management techniques helps sports clubs avoid problems

\section{Recommendations:}

- The need to qualify managers and train them in the methods of leadership and training programs to join them to develop their creative skills.

- The need to encourage club managers to experiment with new methods of work and to highlight creative ideas and bear the calculated risks resulting from these methods.

- The need to adopt the establishment of seminars, lectures and workshops by officials on methods of managing organizational conflict to increase the awareness of managers and give them the concept of collective action.

- Designing specialized training programs on conflict management methods for managers of sports clubs.

- Training club managers on how to diagnose the conflict and identify its causes and ways to deal with $\mathrm{i}$

\section{References}

1 AbdullahAl-Saleem The Effect of Organizational Variables on the Level of Administrative Creativity in the Employees of the Security Services in Riyadh ", Master Thesis, Naif Arab Academy for Security Sciences, Riyadh, 2002

$2 \quad$ Ahmed Maher Organizational Behavior in Building Skills, Dar University , 2002

3 Ahmed Sayed

$4 \quad$ Amer al-Kubaisi

Management of organizational behavior, contemporary vision, 2000

5 Falah Hassan Adai

The Governmental Organization between Contemporary Tradition, Dar Al-Sharq Printing Press, Doha, 1998 al - Husseini

6 Hussein Naji Aref

Organizational Behavior, Dar Yafa Scientific, Jordan, 2001 
7 Isaksen, S.G. \& An exploratory study of the relationships between and Geuens, D. assessment of problem solving study and creative problem solving:. J. of Thinking and Problem Solving, Vol. 17, No. 1, 2007

8 Isaksen, S.G. \& Creative problem solving : the history, development and Treffinger, D.J. implications for gifted education and talent development:, GiKed child Fuarterly, Vol. 49, No. 4, 2005

9 Khair Kamel Organizational Behavior, Dar Safa for Publishing and Distribution, Hamoud Amman, Jordan, 1, 2002

10 Mahmoud Organizational Behavior in Business Organizations, Dar Wael Suleiman Al - Publishing, Amman, Jordan, 1, 2002

Omayyan

11 Marion Peters " Resolving Conflict in nonprofit organizations" Wilder Angelica Foundation , 2004

12 Mclean, E.M. Examining the rela=onship between individuals creative products and their creativity styles:, Master of Science, Buffalo State college, Buffalo, New york , 2004

13 Rahim A. "Managing Conflict in Organizations", 3rd Ed., Westport: Greenwood Publishing, Inc , 2001

14 Randa Al Zahri Administrative Creativity in the Shadow of Bureaucracy, The World of Thought, Kuwait, 2002

15 Ray, D.K. Impact of group member creative style on creative problem solving process in a technology - mediated environment:, Diss. Abs. Int., Vol. 68, No. 7, 2008

16 Salah al-Din Abdel- Effective Behavior in Organizations, Dar University Alexandria, Baqi 2004

17 Salem Al Qahtani Organizational Constraints for Creativity in Administrative Development Personnel in Governmental Bodies in Saudi Arabia, Journal of King Saud University, Administrative Sciences 2, Volume 14, 2002

18 Wasel Jamil al Organizational Climate and Conflict Management in Educational moemen Institutions, Amman, Dar Al-Hamed Publishing and Distribution, 2011 
